\title{
Privatisation, human rights and security: Reflections on the Draft International Convention on Regulation, Oversight and Monitoring of Private Military and Security Companies
}

\author{
LAURENCE JUMA \\ Associate Professor, Faculty of Law, Rhodes University
}

\section{INTRODUCTION}

In July 2010 the United Nations Working Group on Use of Mercenaries as a Means of Violating and Impeding the Exercise of Rights of Peoples to Self-Determination ("the Working Group") ${ }^{1}$ presented its Draft International Convention on the Regulation, Oversight and Monitoring of Private Military and Security Companies ("the Draft Convention") to the $15^{\text {th }}$ session of the Human Rights Council in Geneva. ${ }^{2}$ A year before, the UN Commission on Human Rights had mandated the Working Group to consult with academic institutions, NGOs and other related bodies so as to establish the "content and scope of a possible draft convention on private companies offering military assistance, consultancy and other military security-related services on the

1 The Working Group, composed of five independent experts, was established by the UN Commission on Human Rights in 2005 to monitor and conduct research on mercenaries and mercenary-related activities. It took over from the office of UN Special Rapporteur on the Use of Mercenaries that had been in existence since 1987, whose terms of reference had largely been overtaken by the changes in the global security landscape after the demise of the cold war. See Del Prado J "Private and security Companies and the UN Working Group and the Use of Mercenaries" (2009) 13 (3) Journal of Conflict \& Security Law 429.

2 See the Draft of a possible Convention on Private Military and Security Companies (PMSCs) for consideration and action by the Human Rights Council, annexed to the Report of the UN Working Group on the Use of Mercenaries as a Means of Violating and Impeding the Exercise of Rights of Peoples to Self-Determination (A/HRC/15/25, 5 July 2010) available at http://www2. ohchr.org/english/issues/mercenaries/docs/A.HRC.15.25.pdf (accessed 30 October 2010). 
international market". ${ }^{3}$ The Working Group was also directed to share with member states the "elements for a possible draft convention on private military and security companies, requesting their input on the content and scope of such a convention". This mandate merely added impetus to an ongoing process that the Working Group had been engaged in since 2006, which had already yielded several drafts of a proposed law. ${ }^{4}$ The current proposal consolidates all these efforts and promises to establish a more effective regime for PMSC regulation.

Since preparing the first draft of a possible convention the Working Group members have been on the road, soliciting support for their initiative all over the world. So far they have been to Latin America, the Caribbean, ${ }^{5}$ Asia and the Pacific, ${ }^{6}$ Africa $^{7}$ and the Western European region. ${ }^{8}$ Whereas the Latin American, Asian and African countries have at least signified their support for some form of binding international framework for the regulation of PMSCs, Western nations, mainly the USA and the UK, have expressed serious doubts about the necessity of a multilateral regime of this kind. Their opposition can be broken down into five main arguments. Firstly it is contended that the existing international regulatory mechanisms for PMSCs are sufficient; what the world needs is implementation and not a new law. Further, it is said that the effectiveness of existing frameworks, such as the Montreux Document, ${ }^{9}$ or the recently signed International Code of Conduct for Private Security Service Providers, ${ }^{10}$ has not been tested. Secondly, they assert the

3 See UN Human Rights Council Resolution /10/11 of 2009, para 13.

4 The earlier drafts had equally attracted reviews and comments. See, for example, Strydom $H$ "The Overview of the UN Draft Convention on private Military and security Companies" (2009) African Yearbook on International Humanitarian Law 121.

5 A/HRC/7/7/Add.5.

6 On 26 and 27 October in Bangkok. The countries represented at the meeting were Afghanistan, Bangladesh, Cambodia, China, Fiji, the Islamic Republic of Iran, Jordan, Myanmar, Pakistan, Qatar, Samoa, Thailand, Vietnam and Yemen. Of these countries Afghanistan raised the greatest concern regarding the activities of PMSCs: see Report on Regional Consultation for Asia and Pacific on the Activities of Private Military and Security Companies: Regulation and Monitoring (26-27 October 2009, UNGA, A/HRC/15/25/Add.4).

7 Algeria, Angola, Burkina Faso, Cameroon, Central African Republic, Democratic Republic of the Congo, Djibouti, Egypt, Equatorial Guinea, Ethiopia, Madagascar, Malawi, Mauritius, Morocco, Mozambique, Niger, Sierra Leone, Sudan, Uganda, Zambia, Zimbabwe and the African Union Commission sent representatives.

8 The fifth and last regional consultation with the Western European and Others Group on the regulation and monitoring of the activities of PMSCs was held in Geneva on 14 April 2010. It was attended by representatives from Australia, Austria, Canada, Finland, France, Germany, Greece, Italy, the Netherlands, Norway, Spain, Sweden, Switzerland, Turkey, the United Kingdom and the United States of America, as well as the European Union: see A/HRC/15/25/Add.6.

9 This document was produced by a joint effort of seventeen countries: Afghanistan, Angola, Australia, Austria, Canada, China, France, Germany, Iraq, Poland, Sierra Leone, South Africa, Sweden, Switzerland, the United Kingdom, Ukraine, and the United States of America. The PMSC industry and the NGO community were also represented. The text is available at http://www.un.org/ga/search/view doc.asp?symbol=A/63/467 (accessed 23 May 2009).

10 Available at http://www.dcaf.ch/privatisation-security/index.cfm (accessed 12 November 2010). The Code was signed in Geneva on 9 November 2010 by 58 companies. See Harwood M "ASIS members sign private security contractors code of conduct" available at 
lack of agreement on what constitutes an "inherent" government function - i.e., that which could legally be excluded from privatisation. Thus, attempting to legislate on the issue effectively compromises the efforts to achieve standardisation of fundamental principles for the national regulation of the industry. Thirdly, the Working Group is said to have over-stepped its mandate by attempting to bring about legislation to deal with a purely human rights issue; the mandate of the Working Group is interpreted as being limited to investigating mercenary activity and assisting member states in eradicating the menace. Fourthly, it is argued that the licensing procedure suggested by the Draft Convention will be costly for some states; and, lastly, it is said that an international treaty such as the one envisaged needs broader consultations than had been carried out thus far.

The position adopted by Western nations may not have been totally unexpected, but the arguments they raised forecast some of the challenges that the Working Group is likely to face in its effort to garner support for the draft law. Although, from an ideological standpoint, factors that influence Western opposition to multilateral legal regimes are often subjective, there is no denying that treaty-making is all about achieving consensus on matters of transnational concern. ${ }^{11}$ This notwithstanding, it may be instructive to note that the wheels of normative change, at the international level at least, are no longer solely driven by the whims of the powerful states but by the combination of a wide variety of interests and activities bringing together governments, transnational entities and networks, civil society and the academic lobby from all parts of the world. This is what happened with treaties enacted in the last two decades, such as the Weapons Conventions and the Rome Statute for the International Criminal Court, ${ }^{12}$ and is likely to be the case with the proposed PMSC Convention. The test, in my view, should be whether, over and above the subjective criteria upon which Western opposition to the law are based, there are fundamental

http://www.securitymanagement.com/news/asis-members-sign-private-security-contractorcode-conduct-007877 (accessed 22 November 2010).

11 This assessment is particularly true of the US approach to multilateral human rights treaties. See Bradley C "Unratified treaties, Domestic Politics and the US Constitution" (2007) 48(2) Harvard International Law Journal 307; Devenmack R \& M Hoffman "Just scraps of paper? Dynamics of multilateral treaty making" (2008) 43 (2) Cooperation and Conflict 185; Prins B \& B. Marshall, "Senate influence or presidential unilateralism? An examination of treaties and executive agreements for Theodore Roosevelt and George Bush" (2008) 26 (2) Conflict Management and Peace Science 191.

12 See, for example, Malanczuk P "The International Criminal Court and landmines: what are the consequences of leaving US behind?" (2000) 11(1) European Journal of International Law 77 (Analysing the reasons and consequences of US not supporting the Ottawa and the ICC treaties); Kervers D "Strengthening Compliance with the Biological Weapons conventions: The protocol negotiations" (2002) 7(2) Journal of Conflict Security Law 275(discussing US refusal to support the Draft protocol). See also Michie A "The provisional application of arms control treaties" (2005) 10(3) Journal of Conflict Security Law 345; Georghiades K "The Ottawa Convention: meeting the challenges of anti-personnel mines" (1998) 14(3) International Relations 51; Van Woudenberg N "The long and winding road towards an instrument on cluster munitions" (2007) 12(3) Journal of Conflict Security Law 447. 
limitations to the Draft Convention that may render its mission impossible to achieve or its role merely cosmetic.

This article will not confront the arguments against the Draft Convention directly but, rather, will analyse in a holistic manner the proprietary promise of the law in light of the broad concerns that have led to the entrenchment of the PMSC issue in the normative agenda of the international community. It will begin by contextualising the draft law within the broader PMSC debate and summarising the essence of its regulatory regime. Three broad themes will then be elicited and analysed to provide insights on the viability of the draft law. These are: the overall question of state responsibility and how it affects enforcement of rules; the use of force and the concomitant notion of inherent state functions; and the oversight and monitoring mechanisms. The objective assessment of how the draft law covers these themes will reveal a consistent pattern of a shared responsibility between PMSCs themselves, the host states and the contracting states to create a more "acceptable" environment for PMSC operations. The article concludes that the draft law, burdened as it is with the ideology of privatisation and the free market, has not departed from the international template for oversight of private entities which often does no more than create weak and ineffective systems. Nonetheless, the article acknowledges that the draft law is still a worthwhile endeavour and one which has greater promise than all other frameworks so far established.

\section{DRAFT CONVENTION IN PERSPECTIVE}

The rise of neo-liberal thinking in the Western hemisphere in the latter half of the last century promoted ideas that were concomitant with privatisation and free trade. ${ }^{13}$ These ideas have facilitated the breakdown of the hegemonic state and the creation of powerful private commercial entities driven solely by the objective of making profit. ${ }^{14}$ When exported to Africa, the neo-liberal agenda created a host of problems. In the first place it has led to the "destruction, not only of prior institutional frameworks and powers (such as the supposed prior state sovereignty over political-economic affairs) but also of divisions of labour, social relations, welfare provisions, technological mixes, ways of life, attachments to the land, habits of the heart, ways of thought" ${ }^{15}$ Secondly, and perhaps most crucially to the discussion here, it has promoted ruthless competition for natural resources; and

13 Neo-liberalism is a theory in political science which justifies the expansion of markets and the promotion of competition and formalism as opposed to the protectionism of the state and other bureaucratic agencies. For discussion of the relationship between neo-liberalism and the state, see Lee S and McBride S "Introduction" in Lee S and McBride S (eds) Neo-Liberalism, State Power and Global Governance in the Twenty First Century (2007) 1.

14 See, generally, Chomsky N Profit and People: Neo-colonialism and Global Order (1999); Juma L "The war in Congo: Shadow networks and the failure of internationalism" (2006) 10(2) Gonzaga Journal of International Law 97.

15 See Harvey D "Neo-Liberalism as Creative Destruction" (2007) 2 (4) Interfacehs available at http://www.interfacehs.sp.senac.br/images/artigos/79_pdf. (accessed 17 April, 2011). 
this could be the reason why most regions in Africa with an abundant wealth of natural resources have become centres of political instability and endless armed conflicts. $^{16}$ Paradoxically, instability anywhere in the world threatens legitimate commerce and diminishes the ability of the state to deliver on other tenets of the neo-liberalist programme. At the same time, combating insecurity in a neo-liberal environment must be balanced against other interests. This is because neoliberalism is not only about trade but also about individual freedoms and rights. Thus, improving global security must contend with limitations brought about by the need to protect human rights and ensure social justice. And that is how private security became a factor in global governance. The only way in which responsibility for human rights violations could be avoided while pursuing national security goals was by promoting the private security industry. ${ }^{17}$ But this aside, in the current world climate any military action taken in pursuit of national interests abroad would be increasingly unpopular if the magnitude of loss of life associated with such action was seen to be unwarranted. Moreover, the option to pursue such interests in a more cost-efficient manner has become extremely compelling, not only in monetary terms but also as a means of improving security governance. ${ }^{18}$ Thus PMSCs are no accident; they are a product of the privatisation and maximisation of profit ideology which drives processes to reorganise the security infrastructure as well as of the concomitant growth of political awareness that inform political choices in the developed world.

Unfortunately, the tension between the free market and the demands of human rights has placed the security debate in the context of war and conflict in Africa in a rather precarious situation. While the neo-liberal order has exposed the vulnerability of the African state, the choice between taking advantage of the free market and its band of private operators, and sticking with their national armies to

16 See, for example, Kurtz M "The social foundations of institutional order: Reconsidering war and resource in third world state building" (2009) 37 (4) Politics \& Society 479; Ross M "What do we know about natural resource and civil war?" (2004) 41 (3) Journal of Peace Research 337; Jensen N \& L Wantchekon "Resource Wealth and political regimes in Africa" (2004)37(7) Comparative Political Studies 816; Lujala P et al "Diamond a curse? Civil war and a 'lootable' resource" (2005) 49 (4) Journal of Conflict Resolution 538.

17 This is because poor performances by PMSCs on the human rights score were less likely to damage the reputation of governments than if the same violations were committed by national armies. This was the case when the US hired MPRI to provide assistance to the Croat forces' advance against Serb positions, which resulted in charges of war crimes against Croat commanders. The US was never blamed for assisting in the violations of international law. See Michaels J "Beyond accountability: The constitutional democratic and strategic problem with privatising war" (2004) 82 Washington University Law Quarterly 1001.

18 See Avant D The Market for Force: The Consequences of Privatising Security (2005) 30, who argues that through proxies states can influence conditions abroad without committing their troops. See also Singer P "Outsourcing War" (2005) 84 Foreign Affairs 119, 125; Cokayane J "Make or buy? Principal-Agent Theory and the regulation of private military companies" in Chesterman $S$ \& Lehnardt C (eds.) From Mercenaries to Market (2007) 196-216; Hawkins D et al "Delegation under anarchy: States, international organisations and principal-agent theory" in Hawkins D et al (eds) Delegation and Agency in International Organisations (2006) 3-38, 7. 
defend constitutional standards, is still a delicate one. All through the continent, we see a mix of approaches as weak and illegitimate governments struggle to find a balance. ${ }^{19}$ The common denominator, so far, is hatred of mercenaries, which is boldly articulated in the African Union Mercenary Convention ${ }^{20}$ and reinforced by the UN Mercenary Convention. ${ }^{21}$ But, beyond mercenaries, there is no effective debate on the private security industry and how it affects regional and international peace. Yet the numbers of PMSCs operating in the continent are growing and their work spreading across many sectors - some are employed by relatively peaceful states to train their armies, others contracted to assist with peace-building and reconstruction efforts, while a significant number are involved in areas of active armed conflict such as in Darfur and Somalia.

Privatisation of security all around the world has come at a heavy price. PMSCs have been accused of disregarding rules of international humanitarian and human rights law in all places where they work. Incidences of unlawful killings, cases of human trafficking, illegal labour practices and several other transgressions by PMSC operatives have been well documented. ${ }^{22}$ The hue and cry against PMSCs has heightened the need for an effective regulatory framework for their operations. The response has been varied: from self-regulatory schemes by PMSC associations to non-binding instruments by regional organisations and blocs of states. What has been missing is a binding international framework that prescribes standards for private security operators and places responsibility on governments to account for the activities of PMSCs working within their jurisdictions.

\subsection{The Purpose of the Draft Convention}

During consultations that preceded the preparation of the Draft Convention, various constituencies expressed the need for an overarching and binding international framework for the regulation of PMSC activities. ${ }^{23}$ It is not surprising, therefore, that the Convention outlines its main objective as the need to fill the "important gaps ... in national and international legal regimes applicable to private military and

19 See generally, Musah A \& Kayode J Mercenarism: An African Security Dilemma (2000).

20 The Convention of the OAU for the Elimination of Mercenarism in Africa OAU Doc CM/433/Rev. L. Annex1 (1972) adopted in Libreville on 3 July 1977 and entering into force on 22 April 1985.

21 See the International Convention against the Recruitment, Use, Financing and Training of Mercenaries, A/RES/44/34, entered into force on 20 October 2001.

22 See, for example, Zarate J "The Emergence of the New Dog of War: Private International Security Companies, International Law and the New World Order" (1998) 34 Stanford Journal of International Law, 34; Amann D “Abu Ghraib" (2005) 153(6) University of Pennsylvania Law Review 2085; Chesterman S “Leashing the Dogs of War” (2005) 5(1) Carnegie Reporter 37.

23 See, for example, "Expert Group on Mercenaries Concludes Visit to Afghanistan", available at http://www.reliefweb.int/rw/rwb.nsf/db900SID/EGUA-7QWSR7?OpenDocument (accessed 25 October 2010). See also the remarks by Samira Safarova, the representative of Azerbaijan, and Octavio Augusto, representative of Brazil, during the $15^{\text {th }}$ Session of the Human Rights Council Meeting in Geneva (fn 2 above). 
security companies". ${ }^{24}$ Apart from this objective, the Convention articulates several other responses to the PMSC problem that are essential to the regulatory regime it seeks to establish. Key among these are creating a regulatory framework that would ensure that PMSCs observe international humanitarian and human rights law; providing a framework for regulating not only the conduct of private military and security companies but also their relationship with member states of the UN by establishing the range of functions that may not be undertaken by such companies; harmonising the full breadth of international instruments that have a bearing on PMSCs; and setting agreeable legal standards for regulation of PMSCs. ${ }^{25}$

The Draft Convention may be an instrument of multifaceted tasks, but its legitimacy still rests on the acknowledgement that a universally conceived framework with political support of nation states has a better promise of reining in PMSCs than self-regulatory frameworks. But the question which is relevant to the discussion here is whether the objectives of the draft law as outlined in article 1 could be achieved other than through a multilateral treaty. ${ }^{26}$ In other words, is the need for a binding treaty based on an objective assessment of the threat that PMSCs pose? Moreover, given the rather uncertain terrain of the international treatymaking process, ${ }^{27}$ can the draft law be rationalised on the basis that it guarantees the attainment of relative or absolute gains as far as the containment of PMSCs is concerned?

There are no obvious answers to these questions. Usually, treaties may be enacted to curb a phenomenon that constitutes a global threat. The treaty could then be seen as an expression of political commitment to deal with the problem. From a social constructivist perspective, a multilateral treaty could be the means of galvanising cooperation among states towards ensuring that unacceptable behaviour occurring in the international space is eradicated. No wonder "contractual international law and multilateralism have become the dominant institutional practices governing modern international society". ${ }^{28}$ The Draft Convention somewhat fits within this paradigm. This is discernable, first of all, from the reports of the Working Group on its interaction with the various constituencies, during the preparatory stages of the Draft Convention. The reports reveal a consistent demand by various country representatives for a multilateral regime to curb PMSC behaviour. ${ }^{29}$ Secondly, provisions of the draft law itself indicate a higher purpose that can only be achieved through multilateralism. For example, its attempt

24 Preamble, para 21.

25 See Preamble, para 2, 7, 11and 23. The objectives are further distilled in art 1.

26 In international parlance, the role of treaties is often a contested one. For example, Mersheimer argues that the whole idea of cooperative multilateral interaction is a chimera. See Mersheimer J "The false promise of international institutions" (1994/5) 19 International Security 5.

27 Denemark R \& Hoffman M "Just Scraps of paper? The dynamics of multilateral treaty making" (2008) 43 (2) Cooperation \& Conflict 185.

28 Reus-Smit C "The constitutional structure of the international society and the nature of fundamental institutions" (1997) International Organizations 555 at 558.

29 See, for example, the Afghanistan report (fn 23 above). 
to define "inherent functions of the state", which none of the other instruments has done, may be limited but nonetheless useful in demarcating zones in which privatisation may be excluded. Also, the rather pervasive affirmation of the role of international law, human rights and international humanitarian law is crucial to the processes aimed at achieving the effective regulation of PMSCs. In this way the draft law and its institutions add to the already existing enforcement mechanisms for human rights and of international humanitarian law. The anticipation is that it will take advantage of the experiences of the institutions created under these regimes to establish a more robust international monitoring and oversight regime for PMSCs more than could ever be expected of self-regulatory and non-binding mechanisms.

\subsection{Overcoming the definitional conundrum}

Before PMSCs acquired the legitimacy that they enjoy today, they were defined relative to their difference with outlawed mercenaries. ${ }^{30}$ Although both provided military and security services for profit, significant differences in their modus operandi were noted. ${ }^{31}$ While mercenaries were bands of rogue soldiers roaming the African continent and overthrowing governments, PMSCs were well-organised business entities whose services were offered in legitimate circumstances. And while PMSCs were totally outside the radar of domestic and international legal regimes, mercenaries were banned by a host of regional and international instruments. ${ }^{32}$ But these differences have not in the least helped to define what PMSCs are for purposes of placing them under an international regulatory regime.

The general understanding is that PMSCs are corporations that offer military or security-related services for monetary gain. ${ }^{33}$ Recent attempts at defining PMSCs have laid emphasis on their functional attributes. For example, according to the Montreux Document, PMSCs are "private business entities that provide military and/or security services, irrespective of how they describe themselves". ${ }^{34}$ The document then describes the kinds of activities that such entities may be involved

30 Earlier works on mercenaries used various methods to make the distinction. Singer's "end of spear" metaphor is a good example. See Singer P Corporate Warriors: The Rise of Privatized Military Industry (2003). See also Zarate (fn 22 above).

31 Messner J "Working towards effective legislative and regulatory solutions for private security industry in Africa" in Gumedze S (ed) Elimination of Mercenarism in Africa: A Need for a New Continental Approach (2008) 145.

32 See Cowling $M$ "Outsourcing and Military: Implications for international humanitarian law" (2007) 32 South African Yearbook of International Law 313.

33 Gillard defines them as "corporations that perform functions traditionally performed by security or military apparatuses of the state": see Gillard E "Business goes to war: Private military/security companies and international humanitarian law" (2006) 85 International Review of the Red Cross $525,526$.

34 Montreux Document, para 9. Military and security services are further defined to include "armed guarding and protection of persons and objects, such as convoys, buildings and other places; maintenance and operation of weapons systems; prisoner detention; and advice to or training of local forces and security personnel". 
in. It is apparent from this definition that the status of PMSCs should be discernable from what they do - a functional approach that deviates from the often-used classification based on their proximity to or involvement in combat operations. ${ }^{35} \mathrm{It}$ further defines PMSC personnel as "persons employed by, through direct hire or under a contract with, a PMSC, including its employees and managers". Obviously, this narrows down the category of persons that may incur responsibility on behalf of the PMSC and recognises the element of "subcontracting" that is prevalent in the private security industry. ${ }^{36}$ What is striking about this definition is that it avoids engagement with what has become the most contentious issue of PMSCs operations in conflict zones - their involvement in actual combat. Although it recognises that PMSC personnel may be "incorporated into regular armed forces of a state", or that their personnel may qualify as "persons accompanying the armed forces" in terms of article 4A (4) of the Third Geneva Convention, ${ }^{37}$ the document creates the impression that entities involved in combat operations, other than within the narrow limits of paragraph 26, do not come under its ambit. At the same time the document leaves it to the discretion of states to determine the kinds of services that may be contracted out, but cautions them to take into account the question whether such services "could cause PMSCs personnel to become involved in direct participation in hostilities". ${ }^{38}$

The Draft Convention does not significantly deviate from the Montreux Document. It defines a PMSC as a "corporate entity which provides on a compensatory basis military and or security services including investigation services, by physical and or legal entities". ${ }^{39}$ Military services are further defined to include "specialised services related to military actions" such as strategic planning, intelligence, investigation, land, sea or air reconnaissance, flight operations of any type, manned or unmanned, satellite surveillance, military training and logistics, material and technical support to armed forces, and other related activities. Security services, on the other hand, are defined to include armed guarding or protection of buildings, installations, property and people, police training, material and technical support to police forces, elaboration and implementation of informational security measures and other related activities. ${ }^{40}$

35 Cockayne J "Regulating Private Military and Security Companies: The Content, Negotiation, Weakness and Promise of the Montreux Document" (2009) 13(3) Journal of Conflict \& Security Law 401, 406.

36 Para 31 of the document deals with subcontracting and places obligations on principals to ensure that notification is made to the state; they demonstrate that subcontractors have authorisation; and that the principal is liable for the conduct of the subcontractor.

37 See para 26(b) and (c). An elaborate discussion of art 4A of the Third Geneva Convention can be found in Fleck D et al, The Handbook of Humanitarian Law in Armed Conflict Oxford: Oxford University Press (2000) 95.

38 See Part II para 1.

39 Art 2.

40 Art 2(c). 
Although, like the Montreux document, the Draft Convention adopts a functional definitional approach, it thus makes a distinction between "military" and "security" services, presumably to canvass a wider understanding of the roles that PMSCs play in modern military operations. However, the definition does not include combat operations, and perhaps this is in tandem with articles 8 and 9 which prohibit involvement of PMSCs in governmental functions (defined to include direct participation in hostilities) and outlaws the use of force. Nonetheless, the definition is open-ended with the possibility that states can determine the ranges of activities that may be outsourced.

The Draft Convention avoids the use of the word "mercenary" in its text. The only miniature reference is in the Preamble where the UN and the OAU Conventions on mercenaries are mentioned. This was probably a compromise after PMSC organisations vehemently criticised the earlier draft that had expressly called for ratification of the anti-mercenary instruments as measures towards regulating PMSC activity. Nonetheless, some authors have called for an express prohibition of mercenarism in the Convention so as to separate PMSCs that carry out legitimate activities from the shadowy ones that harbour mercenaries and engage in mercenary activities. ${ }^{41}$ But this is unlikely to happen, given current trends. The question is whether it is desirable to proceed as though all mercenaries have been eliminated and their sins completely purged.

\section{THE PRINCIPLE OF STATE RESPONSIBILITY}

The challenges to regulating activities of PMSCs arise from their transient character, which makes it difficult to subject their operations to an effective oversight regime. Most PMSCs are hybrid in nature, and their status, even operations, traverse the worlds of business, of the military and of humanitarianism. This makes it difficult to assign them to a single regulatory regime. The problem is compounded by the fact that PMSC activities blossom in conditions of armed conflict, where governmental authority is heavily contested or non-existent. In the African context, the problem is exacerbated by ineffective domestic legal systems and widespread complicity of governments in the illegal activities of PMSCs. ${ }^{42}$ Thus, PMSC operators are rarely brought to court within jurisdictions where they work. This has been particularly true of Iraq, Afghanistan, DRC and Sudan. ${ }^{43}$ Further, although governments are the

41 See, for example, Gumedze S "Addressing the use of private security and military companies at the international level" ISS Paper 201 (November 2009) available at http://idl-bnc.idrc.ca/ dspace/bitstream/10625/41432/1/129208.pdf (accessed 12 June 2010).

42 The often-cited example is that of President Ahmed Tejan Kabba of Sierra Leone who engaged the services of Executive Outcomes, a South African mercenary outfit, to repel RUF assault on Monrovia during the civil war. See Francis D "Mercenary intervention in Sierra Leone: Providing national security or international exploitation" (1999) 20 Third World Quarterly 319.

43 In Iraq the US transitional authority granted immunity from prosecution under Iraqi law to all PMSC operators. See Order 17 of the US Coalition Provisional Authority, signed in December 
main clients of PMSCs, they have persistently denied accountability for the misconduct of PMSCs, not to mention the demonstrable ambivalence towards preventing or enforcing international standards against these entities. ${ }^{44}$ Therefore it makes practical sense to expand the responsibility of states in this regard. The idea seems to be that, since the locus of PMSC activity is within the jurisdiction of states, and states are the subjects of international law, the rules of state responsibility should derivatively impact upon PMSCs.

\subsection{The international law of state responsibility}

Under international law, state responsibility indicates the consequences of a breach of international obligations by states and enunciates the ranges of acceptable responses to such breaches. ${ }^{45}$ This principle is well grounded in international law and has been affirmed by international courts and tribunals. ${ }^{46}$ The responsibility rests on states because they are the primary subjects of international law. The international law rules on state responsibility are currently derived from the Draft Articles on Responsibility of States for Internationally Wrongful Acts ("Draft Articles") developed by the International Law Commission and adopted in $2001 .^{47}$

Under the Draft Articles an act will be wrongful if it is "attributable" to a state under international law and constitutes a breach of the international obligations of the state. Ordinarily government officials will have both inherent and sometimes ostensible authority to bind the state. Thus, any wrongful act that they commit will be attributable to the state. ${ }^{48}$ What presents some difficulty is how to determine "attribution" where an activity is carried out by an entity which is not part of the government. This is particularly problematic in cases of PMSCs that operate in conflict zones. Under article 4 of the ILC rules the act of an entity may be attributed to a state if the entity is acting as a state organ. It is therefore apparent that where a

2006. Several cases arising out of the conduct of PMSCs in Iraq have been tried in the US; for example, US v Pissaro, No 5:04-CR-211-1(E.DNC. June 17, 2004). See also Stinnet N "Regulating the privatization of war: How to stop private military from committing human rights abuses" (2005) Boston College International \& Comparative law Review 211.

44 Gaston E "Mercenaries 2.0? The rise of the modern private security industry and its implications for international law enforcement" (2008) 49 (1) Harvard International Law Journal 221.

45 Art 1 of the International Law Commission (ILC) Articles on the Responsibility of States for Internationally Wrongful Acts provides that "Every internationally wrongful act of a state entails the international responsibility of that state".

46 See, for example, Chorzow Factory (1927) PCIJ ser. A no. 9; Corfu Channel Case, ICJ Reports (1949) 23. In Chorzow the court defined state responsibility as a principle of international law involving an "obligation to make reparation for any breach of an engagement".

47 These rules are generally considered to have acquired the status of customary international law. See Wolfrun R "State responsibility for private actors: An old problem of renewed relevance" in Ragazzi M (ed) International Responsibility Today (Brill 2005) 424; Kiss A "State responsibility and liability for nuclear damage" (2005) 35 (1) Denver J. Int'l. L. \& Pol. 67, 77.

48 For example, enforced disappearance such as in Velasquez Rodriguez $n$ Honduras, Merits , InterAmCtHR, Ser C, No \$ (1989); 95 ILR 259 para 183. 
PMSC acts as an organ of state, and not as an independent contractor, state responsibility will be incurred. ${ }^{49}$ In this regard the source of authority could be founded on some legislation or decree, and the conduct would exhibit some colour of national authority. This is the case where, for example, PMSC personnel are incorporated in the state military or their activities are subordinated to government. However, subordination is not always easy to prove because most PMSCs are contracted as independent entities carrying out professional services. The determination as to whether PMSC personnel operating in any theatre of conflict have been incorporated into the state military must depend on the command and internal discipline tests provided for in article 43 of the First Additional Protocol to the Geneva Conventions. Rarely do PMSCs get incorporated into state armies; thus the probability of states incurring responsibility in terms of article 5 is minimal.

PMSC actions may also be attributed to the state where they are exercising governmental authority. ${ }^{50}$ In Case Concerning Armed Activities in the Territory of Congo (DRC v Uganda) ${ }^{51}$ Uganda had advanced the argument that its soldiers (UPDF) were not acting in the capacity of persons exercising governmental authority while in the territory of the DRC. This argument was dismissed as the court found that the conduct of individual soldiers and officers of the UPDF were the conduct of a state organ. Thus, authority may be explicit from the nature of activity that a PMSC is required to perform. In most cases however, it is very difficult to find a nexus between activities of PMSCs and express governmental authority. A combination of factors must then be considered. For example, it may be necessary to examine how the power was conferred, the purpose for which the power was conferred and the extent to which the PMSC is accountable to the government. Indeed, if the power being exercised by the PMSC does not further any sovereign objective of the state, it may not be attributable to the state.

Commentators have suggested that the nature of the activity is crucial because some are more attributable to the state than others. ${ }^{52}$ If PMSCs are engaged in policing, or detention pursuant to judicial sentence then the authority may be explicit. Similarly, if they conduct interrogations, this may be attributable to the

49 See art 4 of ILC. In the Case Concerning Application of the Convention on the Prevention and Punishment of Crime of Genocide (Bosnian and Herzegovina v Serbia and Montenegro), the ICJ found that, although Serbia was not responsible for the Srebrenica genocide, it was still in breach of the Convention for failure to prevent the genocide and for not punishing the perpetrators. In the Court's view the determination as to whether the action were attributable to the respondents depended on whether the acts were committed by organs of respondents or whether the agents were acting on the "instrument of or under the direct control of the respondent". It found that the entities or persons who carried out the massacre were not completely dependent on federal authorities in Belgrade, nor were they acting under Belgrade's instructions. For in-depth discussion of the decision see Dimitrijevic V \& M Milanovic "The strange story of the Bosnian Genocide case" (2008) 21 Leiden Journal of International Law 65.

50 Art 5.

51 CJ Reports (2005), 168.

52 See, for example, Hoppe C, "Passing the buck: State responsibility for private military companies" (2008) 19 (5) European Journal of International Law 991. 
state more than just guarding installations. But the question of authority in international law also hinges on the level of control that the government has on the PMSC. In Nicaragua, for example, the ICJ observed that conduct may give rise to legal responsibility if it is proved that the state had "effective control" of the operations that resulted in the alleged violations of international law. ${ }^{53}$ The United States government had assisted in financing and training the contras and also participated in the planning and supervision of their military operations. Despite US involvement, the acts of the contras were not "attributable" to the US, thus could not give rise to legal responsibility on its part. ${ }^{54}$ The Court argued that, for the conduct of the contras to give rise to such responsibility, "it would in principle have to be proved that the state had effective control of the military or paramilitary operations in the course of which the alleged violations were committed". ${ }^{55}$ More recently the "effective control" test was affirmed by the ICJ in the Bosnian Genocide case. ${ }^{56}$

The other limb to the attribution test is provided for in article 8 of the draft Convention. Here, attribution may occur when PMSCs are directed or controlled by the state. This is only possible if the wrongful act committed by a PMSC is the result of a direct order by the state or was performed under the direct control of government. However, if for any reason the act was beyond the scope of authority conferred on the PMSC, the state will be excused from liability. This rule (ultra vires) has obviously come under heavy criticism from scholars. ${ }^{57}$ The suggestion put forth is that, if there is "apparent authority", states should not be shielded from responsibility. Still, the PMSC activity under scrutiny must have a cognisable nexus with the authority conferred, and this is never easy to prove in conflict situations where even the status of government is contested.

\subsection{Topology of state responsibility under the Draft Convention}

The Draft Convention creates a framework through which state responsibility can be incurred in respect of certain acts of PMSCs, without necessarily satisfying the

53 Military and Paramilitary Activities In and Against Nicaragua, Merits judgment (Nicaragua $v$ USA) ICJ Reports 1986, p 14 para 115.

54 Note, however, that the court still found the United States responsible for its own conduct - that of training and financing the contras and carrying out specific operations, including the mining of the Nicaraguan harbour - which the court classified as wrongful conduct: ibid, paras 75-80, 238, 242.

55 Ibid para 115.

56 Compare the "effective control" test with the "overall control" test in the ICTY case of Prosecutor $v$ Tadić (Case No IT-94-1-A, Judgment of the Appeals Chamber). According to the ICTY, "overall control" is achieved when the state "has a role in organising, coordinating and planning the military action of the military group, in addition to financing, training and equipping or providing operational support to that group" Para 137. See Casese A "The Nicaragua and Tadić tests revisited in light of the ICJ judgment on Genocide in Bosnia" (2007) 18(4) European Journal of International Law 649; Vité S "Typology of Armed conflicts in international humanitarian law: Legal concepts and actual limitations" (2009) 91 International Review of the Red Cross 69.

57 See for example, Browlie I Principles of Public International Law 7ed. (2008) 452. 
traditional rules of international law discussed above. This is a useful innovation, and it is what sets the Draft Convention apart from other treaty regimes. But, before examining how individual activities of PMSCs are treated in the Draft Convention, certain general rules of responsibility need to be clarified. First, the Convention categorises states into four kinds (contracting states, states of operation, home states and third states) and assigns responsibility accordingly. ${ }^{58}$ But irrespective of the division, states will still bear responsibility "for military and security activities of PMSCs registered or operating in their jurisdiction, whether or not these entities are contracted by the state". ${ }^{9}$

Thus it will no longer be necessary to prove "attribution" or "subordination", as is the case under the general rules of international law, to hold a state responsible for the activity of PMSCs. This provision has profound implication for states and PMSCs alike. Take for example the controversy around AEGIS Defence Services Ltd, a British company that secretly relocated its offices to Basel, Switzerland, in October $2010 .^{60}$ Its owner, Tim Spencer, was the man behind the infamous Sandline operations in Sierra Leone at the height of the civil war in that country. In the recent past Tim Spencer has reinvented himself and his company has been able to attract contracts from the US government for services in Afghanistan and Iraq. The company is also known to be extending its network to Africa, perhaps in less controversial circumstances than the past. However, for purposes of our analysis, if Switzerland were a state party to the Draft Convention it would have to license and register the company under its domestic regime and also bear responsibility for the military and security activity of AEGIS all over the world. In fact, victims of violations perpetrated by AEGIS personnel working in Africa would no doubt be quite happy to bring their claims against Switzerland rather than their own governments. They would also be able to shop for a convenient forum to bring such a suit. This in itself may act as major deterrent to allowing rogue PMSCs to operate within the territory of a state.

Secondly, the Draft Convention distinguishes between "inherent" state functions, which cannot be delegated and for which the state takes direct responsibility, and those functions that are not such and can thus be delegated, therefore giving rise to functional international responsibility on the part of PMSCs. ${ }^{61}$ This is to ensure that states preserve their sovereignty and do not abdicate their responsibility towards their citizens and other states. That is perhaps the reason why article 9 expressly prohibits the delegation or outsourcing of such functions. Related to this is a

58 Art 2 (j-m). It should be noted however, that most aspects of responsibility under the Draft Convention overlap, and so states may generally bear liability despite this categorisation.

59 Art 4(1).

60 The relocation sparked off riots in the city of Basel: see Smith R "British Mercenary not welcome in Switzerland" Linksunten.Indymedia.org available at http://linksunten.indymedia. org/de Lnode/26589 accessed 1 November 2010); Dacey J "Swiss fired up over arrival of mercenary firm" (Swiss.info.ch) available at http://www.swissinfo.ch/eng/business/Swiss fired up over arrival of mercenary firm.html?cid=22482084 (accessed 1 November 2010).

61 Art 2. 
requirement for states to ensure that PMSCs act in accordance with international human rights law and international humanitarian law. Apart from the general duty to take legislative and other measures to establish and uphold the rule of law, ${ }^{62}$ states are specifically enjoined to ensure that contracts or agreements that they enter into with PMSCs do not frustrate this goal, and that the personnel of PMSCs respect the law. ${ }^{63}$

Thirdly, the draft law extends responsibility to intergovernmental organisations (INGO). ${ }^{64}$ This is realistic because these organisations use PMSCs in various aspects of their work. $^{65}$ In Africa PMSCs are assisting in peacekeeping operations, humanitarian assistance and increasingly, in peace-building and reconstruction efforts. ${ }^{66}$ In Sierra Leone, for example, PMSCs are an integral part of its security sector reform programme. Unlike in the past, the UN and AU are now engaging the services of PMSCs on a regular basis and may be complicit, just like states, in perpetuating the relative impunity of PMSC operatives. ${ }^{67}$ The Draft Convention's approach is thus welcome and should be supported.

\subsubsection{Responsibility with regard to the use of force}

The prohibition on the use of force by PMSCs is contained in article 8 of the Draft Convention. States are required to take measures to prohibit PMSCs from engaging in direct hostilities or other acts that may result in overthrowing governments, changing internationally recognised borders, violating the sovereignty of states or any part thereof and explicitly targeting civilians. The term "direct participation" is not defined by the Convention. What exactly should direct participation entail? Can a PMSC that provides food to soldiers or toilets in combat zones be directly participating in the conflict? Or should direct participation be limited to the actual firing of weapons?

Although a precise definition of the term is hard to find, guidance can be obtained from practices in international humanitarian law ("IHL"). Under IHL civilians in a situation of conflict should not be targeted "unless and for such time as they directly

62 Art 5.

63 Art 7 and 17.

64 Art 3.

65 See generally, Cokayane J Commercial Security in the Humanitarian Space: Blurring Boundaries or Building States (2006).

66 See Spearin C "Private security companies and humanitarians: A corporate solution to securing humanitarian space" (2001) 8 (1) International Peacekeeping 24.

67 For example, in Darfur the AU, with the assistance of the US Department of State, hired Pacific Architectural Engineers to assist with logistical support, including construction of camps, provision of water and food and laundry services. See Appiah-Mensah S "AU's critical assignment in Darfur: Challenges and constraints" (2005) 14 (2) Africa Security Review. See also the essays in Baker D \& M Caporini (eds) Private Military and Security Companies: Ethics and Civil Military Relations (2008); Lynch C "UN Embraces Private Military and Security Companies" at http://w/2010/01/17/u embraces private military contractors (accessed 28 October 2010). 
participate in hostilities" ${ }^{68}$ The notion of "direct participation" is also derived from the phrase "taking no active part in hostilities" found in article 3 common to the Geneva Conventions. The original use of the term in IHL parlance placed much emphasis on the causal link between the act complained of and the resultant harm. ${ }^{69}$ In this way an individual working in an ammunition factory would not be directly participating in the conflict but his counterpart preparing ammunition for use in a warfront would. Likewise a party providing strategic intelligence analysis may not be, but one providing tactical intelligence to combat forces would. ${ }^{70}$ The test falls short if civilian activities fulfil critical aspects of the military endeavour, such as the provision of food or toilets, but appear to be far removed from actual combat operations. In a recent study the ICRC has developed a more nuanced interpretation of the term that goes beyond the causal link test. ${ }^{71}$ The study suggests that direct participation should refer not to the function, status or affiliation of a party, but to their engagement in a specific act during the conflict. The act should be one that is likely to affect military operations or cause death or injury to persons, or destruction to a certain degree ("threshold of harm"). Further, there must be a causal link between the act and the harm that results from it. Also, there must be a belligerent nexus between the act and the manner in which military operations are conducted, which means that the act should be specifically designed to cause harm in support of one party against the other. ${ }^{72}$ According to this rubric, individual acts of PMSC personnel will be crucial to the determination of the nexus (belligerent) as opposed to the general obligations under the contract.

It should also be noted that, whereas the Convention claims that its objective is to identify activities that are "inherently" governmental and therefore cannot be outsourced, its prerogative seems geared towards limiting PMSC involvement in direct hostilities. What it does is to define "inherent" functions as those consistent with the principle of state monopoly on the use of force, such as "direct participation in hostilities, waging war and or combat operations, taking prisoners, law making ....and other functions that a state party consider to be inherently state functions". ${ }^{73}$ Gumedze argues rather convincingly that fundamental state functions are more than

68 Protocol Additional to the Geneva Conventions of 12 August 1949, and Relating to the Protection of Victims of International Armed Conflict (Additional Protocol I) art 51(3), 1125 UNTS 3; Protocol Additional to the Geneva Conventions of 12 August 1949 relating to the Protection of Victims of Non-International Armed conflict (Additional Protocol II) art 13(3), 1125 UNTS 609.

69 See, for example, Schmidt M "Direct Participation in Hostilities and 21 ${ }^{\text {st }}$ Century Armed Conflict" in H. Fischer et al (eds) Festschrift Für Dieter Fleck (2004) 505 at www.michaelschmidt. org/images/directparticipationproofs.pdf (accessed 26 October 2010); Kretzmer D "Civilian Immunity: legal Aspects" in Promoratz I (ed) Civilian Immunity in War (2007) 91.

70 Schmidt M "Deconstructing direct participation in hostilities: The constitutive elements" (2010) 42 International Law \& Politics 509.

71 See International Committee of the Red Cross (ICRC) Interpretive Guidance on the Notion of Direct participation in Hostilities under International Humanitarian Law (prepared by N Melzer) (2009). See also Schmidt M (fn 69 above) 697.

72 Schmidt Ibid.

73 Art 2. 
those consistent with its monopoly on the use of force. ${ }^{74}$ The Convention does not provide a useful grid for determining when functions that are otherwise permissible can slide into the prohibited zone. Moreover, the scope of some of the functions listed is not provided, so one is left to wonder why functions such as intelligencegathering or knowledge transfer within the military should be inherently governmental. It is apparent that what amounts to an "inherently state function" might still need to be rethought.

It is important to note that, as far as PMSCs are concerned, direct participation in armed conflict may result in breach of the Geneva Conventions, which may render their personnel liable to armed attack as legitimate targets. They may also lose their civilian protection under IHL. $^{75}$ In addition, civilians in this situation lack "combatant privilege" and may be punished. ${ }^{76}$

\subsubsection{Criminal responsibility}

Can states commit crimes under international law? This has been a very controversial issue in international law circles. ${ }^{77}$ If a state uses a PMSC to commit acts of aggression or genocide against another state, would the innocent state be able to institute criminal proceedings in an international tribunal? To begin with, the law of state responsibility does not really differentiate between "criminal" and "civil" responsibility. Crawford and Olleson rightly observe that this branch of the law "does not embody classifications" as we may find in domestic systems. ${ }^{78}$ But that notwithstanding, international law is much clearer on individual criminal responsibility. ${ }^{79}$ Persons acting on behalf of a state may incur individual criminal liability if their actions fall within the categories of crimes specified under the Rome Statute of the International Criminal Court (ICC) and also amount to grave breaches of the Geneva Conventions and the Additional Protocol II. Indeed, article 58 of the ILC Articles creates the possibility of finding "individual responsibility under international law of any person acting on behalf of a state".

74 Gumedze S (fn 41 above).

75 Art 13(3) of Protocol II denies civilians the "general protection against the dangers arising from military operations".

76 See, for example, the case of David Hicks (United States $v$ Hicks), an Australian detainee at Guantanamo Bay who was tried for attempted murder of members of coalition forces in Afghanistan. He was classified in the charge, rather dubiously, as an "unprivileged belligerent".

77 See, for example, Abi-Saab G "The Uses of Article 19" (1999) 10 European Journal of International Law 339; De Hoogh A Obligations Erga Omnes and International Crimes (1996); Jørgensen N The Responsibility of States for International Crimes (2000); Pellet A "A New Draft Articles of the International Law Commission...A Requiem for States' Crime" (2001) 32 Netherlands YBIL 55.

78 See Crawford J \& S Olleson "The Nature and forms of international responsibility" in M. Evans (ed) International Law 2ed (2006) 458.

79 See, for example, Lehnardt C "Individual liability of private military personnel under international criminal law" (2008) 19 (5) European Journal of International Law 1051. 
The Draft Convention requires state parties to establish jurisdiction over criminal conduct by PMSCs ${ }^{80}$ and take measures necessary for investigation, prosecution and punishment of violations of the draft Convention. ${ }^{81}$ It also endorses individual criminal responsibility for superiors of PMSC personnel. ${ }^{82}$ In the past PMSC personnel have acted with impunity because no state was ready to assume the responsibility of punishing their transgressions. The Draft Convention seeks to remedy this by creating a multiple system of jurisdictional authority over PMSC conduct. In the framework created by the Draft Convention, a single criminal act could be tried by several countries. States are thereby enjoined to establish jurisdiction over offences committed within their territory, aboard a vessel flying the flag of the state or an aircraft registered in the state or committed by their nationals. The requirement goes further to allow for the exercise of jurisdiction by a state when a national is a victim or the offence is committed by a person who habitually resides in its territory. ${ }^{83}$ States may also choose whether to extradite a person to a state which has established jurisdiction or to try such person itself, if the person is present within its jurisdiction. ${ }^{84}$ The Draft Convention envisages that states would generally exercise jurisdiction not only where the offence is committed within their territory but also when the offender is their national, irrespective of where the offence could have been committed. The other option open to states is that of extradition. ${ }^{85}$ Article 24 makes all offences under the Draft convention extraditable, but this may be subject to any bilateral arrangements or domestic law. However, the Convention invites state parties to modify bilateral or multilateral arrangements to conform to this article.

\subsubsection{Protection of Victims}

The Draft convention establishes responsibility for states to ensure that restitution or compensation is provided for persons who suffer as a result of PMSC violation of the law. ${ }^{86}$ It also calls for the establishment of an international fund for the rehabilitation of victims. ${ }^{87}$ It suggests that such a fund be created under the auspices of the UN and administered by the Secretary General. The fund would provide reparation to victims of offences under the convention and assist in their rehabilitation. The idea of compensation for victims of corporate activities has never been adequately addressed by international law. However, there are indications that

80 Art 21.

81 Art 23.

82 See art 7(3). But the personnel must be under their "effective authority and control". See also Frulli M "Exploring command responsibility of private military contractors" (2010) Journal of Conflict \& Security Law 1.

83 Art 21(2).

84 Art 22(4).

85 See art 24.

86 Art 20 (4).

87 See art 28 . 
international criminal tribunals may be open to considering the issue of compensation for victims. For example, the ICTY rules of procedure provide that the trial chamber may consider claims for reparation and restitution of property after judgment and conviction. ${ }^{88}$ It also provides that judgments of the tribunal will be binding on any national or international courts that are considering claims of compensation by victims. A thinly-veiled recognition of the duty to compensate victims by PMSCs is contained in the recently signed International Code of Conduct for Private Security Service Providers, where the companies committed themselves to ensuring that they have sufficient financial capacity to meet all claims arising from their work. ${ }^{89}$

\section{LICENSING AND OTHER ADMINISTRATIVE CONTROL MEASURES}

While it may be easy for states to simply agree on the promulgation of international standards, it is usually a big challenge to secure effective implementation of those standards. The recognition of the schism between standard-setting and implementation has spawned considerable debate on the viability of the international system as a whole, and questions are being asked as to whether treaty regimes are the best vehicles for resolving international problems. As a consequence of these concerns we now see a general shift from standard-setting to implementation in the promulgation of treaty regimes. More treaties are now creating implementation and monitoring bodies to ensure that state parties are assisted in achieving the objectives of the treaty. Also, treaties are flexibly drafted to take advantage of already existing regimes that bear some similarity to their purpose and have enforcement qualities in them. That is why, in the Preamble to the Draft Convention, recognition is given to existing international regimes that have a bearing on PMSCs. But perhaps much more poignant in this regard is the acknowledgement, and indeed affirmation, that PMSCs and their clients must observe the existing rules of international law.

The Draft Convention envisages a two-level oversight system for PMSCs. The first is the domestic level. Obviously, states are crucial because they have a better organised system for promulgation of rules and enforcement thereof. The Convention demands that states take measures to ensure that PMSCs respect and observe human rights and that their conduct is consistent with international humanitarian law. ${ }^{90}$ At the second level the Convention establishes international oversight mechanisms that operate along the same lines as other UN treaty bodies. The two levels are linked through the principles of complementarity and subsidiarity as known in international law.

88 Rules of Procedure and Evidence of the ICTY, as amended, IT/32/ Rules 105 \& 106.

89 See International Code of Conduct for Private Security Service Providers (fn 10 above), para 69.

90 Arts 5 (1) and 7. 


\subsection{At the domestic Level}

It is common knowledge that protection against the violation of human rights by PMSCs cannot be achieved unless appropriate national and international legislation is adopted and implementation mechanisms are developed so as to ensure enforcement. One important thing that the Draft Convention does is to place responsibility for any military or security activity of PMSCs on the state in whose jurisdiction that PMSC is operating, whether or not that state has contracted the company. ${ }^{91}$ This means that states must take measures to ensure that PMSCs do not violate the law. One way of achieving this objective is by establishing an effective monitoring and oversight regime. The Draft Convention envisages a three-pronged approach that involves legislative intervention, institution-building and a procedural framework. States must, as a prerequisite, enact a "comprehensive domestic regime of regulation and oversight over activities in its territory of private military and security companies and their personnel".$^{92}$ This will enable the state to create a body responsible for monitoring and oversight. The body created will be tasked with implementing a national registration and licensing procedure for PMSCs.

\subsubsection{National institutions for monitoring and oversight}

The Draft Convention enjoins each state to create a governmental body that would act as "national centre for collection, analysis and exchange of information" on activities of PMSCs. ${ }^{93}$ It does not indicate the kinds of structures that such a body should have. Presumably this leaves state parties with latitude in modelling such institutions to fit their particular circumstances. We have seen a variety of national institutions created to promote international standards. The examples that readily come to mind are national human rights organisations. ${ }^{94}$ This idea is therefore not unique. What might be unique is its application to PMSCs. In the past, states have attempted to meet the objectives of regional and international mercenary law by establishing regimes prohibiting their citizens from participating in mercenary

\footnotetext{
Art 4(2).

Art 13.

Art 13(1)(b).

94 See McQuoid-Mason D "The Role of Human Rights Institutions in South Africa" in Hossain K et al (eds) Human Rights Commissions and Ombudsman Offices (2000) 618; Okafor O \& S Agbakwa "On Legalism, Popular Agency and "Voices of Suffering": The Nigerian National Human Rights Commission in Context" (2002) 24 Human Rights Quarterly 662; Reif L "Building Democratic Institutions: The Role of National Human Rights Institutions in Good Governance and Human Rights Protection" (2000) 13 Harvard Human Rights Journal 1.
} 
activities abroad and imposing stringent licensing requirements for any security or military involvement of their citizens abroad.

In South Africa, for example, the Prohibition of Mercenary Activities and Prohibition and Regulation of Certain Activities in Areas of Armed Conflict Act 2006, which is the primary legislation dealing with private military and related services, did not create any regulatory governmental body. Instead, it placed all licensing responsibilities on the National Conventional Arms Control Committee (NCACC) established under the National Conventional Arms Control Act of 2002. The NCACC was established as an arms control mechanism with its capacity geared towards the management of arms licensing processes. It could not be expected to fulfil the broader security concerns that the PMSC industry portends. Thus, the NCACC is a far cry from what article 13 of the Draft Convention envisages.

The Sierra Leonean experience has been different. Having recovered from a long period of instability, the security sector reform agenda has been more focussed and relatively in tandem with current security concerns. Indeed, the legislative scheme with regard to security is perhaps closer to the requirements under the Draft Convention than can be said of any other country in Africa. The overarching legislation for security governance is the National Security and Central Intelligence Act passed in 2002. ${ }^{95}$ The Act created the Office of National Security (ONS) as the central organ for regulation of all private security operatives. ${ }^{96}$ It is this organ that licenses all PMSCs in accordance with set regulations and ensures that PMSCs comply with the Standard Operating Manual for Private Security Companies (SOP) that was promulgated in $2006 .{ }^{97}$ A recent estimate places the number of PMSCs that have been licensed by ONS at 30, although there may be more than 50 operating in Sierra Leone. ${ }^{98}$ The Sierra Leonean experience demonstrates that the requirements of article 13 of the Draft Convention can be achieved and that states could tailor their institutional arrangements to match their particular circumstances.

\subsubsection{Registration and licensing}

95 Other bodies that the Act establishes are the National Security Council (NSC) (chaired by the President), Sierra Leone Police (SLP) and the Republic of Sierra Leone Armed Force (RSLAF). See Conteh K "Security Sector Reform in Sierra Leone and the Role of the Office of the National Security" in P Jackson \& P Albretch (eds) Issues and Themes of Sierra Leone Security System Transformation Process 1997-2007 (2008) 9.

96 Note, however, that apart from its other functions the ONS acts as the secretariat of the NSC.

97 SOP contains guidelines that must be fulfilled before licences can be issued. Such guidelines include minimum wage requirements for personnel, ownership of sufficient and up-to-date equipment, training of personnel in international humanitarian law, human and civil rights, and gender based violence (SOP.5). It also contains guidelines on complaint procedures, especially those that are labour related.

98 See Ralby I "Regulating private security in Sierra Leone" (2010) 5(4) PeaceOps: Journal of International Peace Operations available at http://web.peaceops.com/archives/153 (accessed 2 November 2010). 
Apart from establishing a national body, the Draft Convention requires that state parties establish a legislative scheme that will set procedures for registration and licensing of PMSCs by government, specific requirements for training and experience of their personnel, and also mechanisms for monitoring offshore activities of registered contractors. Much has been said that touches on the issue of licensing. However, it should be mentioned that registration and licensing is perhaps the most effective way of monitoring PMSC activities within the domestic setting. The licensing regime established by the Draft Convention extends beyond the mere authorisation of PMSCs to do business in the territory of a state party. The process must ensure that PMSCs' record of human rights violations and other violations of international law are examined and that due diligence standards are met. Secondly, licensing procedures are also required to be set up in home countries of PMSCs hoping to export their services abroad. Thus article 15 enjoins states to ensure that the export of military and security services occurs in compliance with appropriate licensing procedures. In addition, the Draft Convention requires that home as well as host states share information regarding PMSCs.

\subsection{International Oversight and Monitoring}

In the same spirit, the Draft Convention in article 29 proposes the establishment of a Committee on Regulation, Oversight and Monitoring of Private Military Companies. The committee will add to the list of other UN treaty bodies that have been established along the same lines, such as the Committee on the Elimination of Racial Discrimination (CERD); ${ }^{99}$ the Human Rights Committee (HRC) established under the ICCPR $;{ }^{100}$ the Committee against Torture (CAT) $;{ }^{101}$ the Committee on the Elimination of Discrimination Against Women (CEDAW); ${ }^{102}$ and the Committee on Protection of All Migrant Workers and Members of their Families (CMW). ${ }^{103}$ The composition of the committee is still up for debate. The initial suggestion was that the Committee should have 14 members elected by state parties, who would serve in their personal capacities for a term of four years. In electing the members states will have due regard to their moral standing, impartiality and recognised competence in the fields covered by the Convention as well as geographical distribution. ${ }^{104}$ The committee shall perform four main functions, namely examination of reports, interpretation of

99 Established under art 8 of ICERD. The Committee has competence to consider individual complaints against the state provided the state has accepted its competence (art 14).

100 The Committee is established under art 28 of ICCPR. See the Optional Protocol to ICCPR for the Committee's competence to entertain individual complaints against the state.

101 See art 17 of Convention against Torture and Other Cruel, Inhuman or Degrading Treatment or Punishment.

102 See art 17 of CEDAW.

103 The Convention on the Protection of the Rights of All Migrant Workers and Members of their Families, GA Res 45/158, adopted on 18 December 1990.

104 Art 29(1) 
the Convention, information gathering, dispute resolution and consideration of individual complaints.

\subsubsection{The system of periodic reporting}

The reporting obligations are set out in article 31. Each state party is required to submit a report detailing the "legislative, judicial, administrative and other measures" it has taken to give effect to the Convention. The general wording of this article, particularly the reference to "other measures", is clearly meant to give states greater freedom in deciding what to include in the report. This might be particularly useful because, whereas the object is to report on compliance with the Convention, states might wish to include other legislative measures relating to human rights protection or international humanitarian law generally that may have an indirect bearing on PMSC activity.

Three types of reports are envisaged by the Convention. The first is what could be referred to as "initial reports" which must be filed within a set period after the state ratifies the Convention and thereby assumes its obligations. The second is periodic reports, which must be submitted periodically as the Convention decrees. Lastly, supplementary reports are to be submitted on request of the Committee. The Convention does not set guidelines as to the content of the reports. This is left to the committee. The experience of other UN treaty bodies is that such guidelines may help ensure the uniformity of reports and thus enable the recipient body to obtain a comprehensive picture of the situation in each state with regard to the implementation of the treaty. ${ }^{105}$

The committee must reserve the right to request further information in the form of supplementary reports. The tendency by some states may be to undermine the work of the Committee by supplying reports that claim wholesale compliance with the Convention or are simply too brief or inadequate. In this regard, the committee may invoke the powers under article 31(1) (b) of the Draft Convention to request further reports. The need for periodic reports is to maintain a dialogue between states and the committee on the steps they are taking to meet the objectives of the Convention. It is necessary therefore that the period set should be realistic, taking into account capacity issues since the reporting will need to be considered and helpful feedback rendered.

105 See, for example, General Guidelines Regarding the form and Content of Reports from States Parties under Article 40 of the Covenant (Doc CCPR/C/5; Doc. A/32/44, Apx. IV) adopted by the Human Rights Committee at its 44th meeting, 29 August 1977. See also Bayefsky A "Human Rights and Direct participation: Direct participation in the UN Human Rights System" Proceedings of the Annual Meeting of the American Society of International Law Vol. 95 (2001) 71. 
The reporting system has certain inherent weaknesses that are unlikely to be overcome by the Draft Convention in its present form. First, there is really no way of compelling states to submit reports. Article 32(2) of the Draft Convention provides that, if a report is due for three months, the Committee may notify the state party "of the need to examine the implementation of the Convention in that state party on the basis of any reliable information" that the committee may have received. As experience in other treaty bodies have shown, these reports are extremely valuable to practitioners and researchers because they document state response to activities within its territory. ${ }^{106}$ For this reason, the submission of reports is crucial to attaining the objectives of the Convention. ${ }^{107}$ Apart from notification and polite aidemémoires, the committee should perhaps be allowed to publicise the list of defaulting states.

Secondly, the Convention is silent on procedure to be adopted in examining reports. There is no requirement that representatives of states should be present during the examination of their countries' reports to answer questions or that accredited organisations be allowed to participate in the proceedings. One way in which to ensure quality of the reports submitted to the committee is to allow for broader participation in the examination process. It is usually NGOs and other civil society groups on the ground that would know if the reports are not entirely accurate. Thirdly, the "observations and recommendations" of the committee should be put to more effective use. The Draft Convention merely provides that the Committee will consider the report and thereafter make "observations and recommendations" to be transmitted to the state party. ${ }^{108}$ Perhaps the Convention should allow the Committee more liberty to publicise their recommendations and publicly demand action from states. In this way the reporting process could have more teeth and also be consistent with the overall purpose of the Draft Convention.

In the same spirit, the Draft Convention should have provided for submissions of "alternative reports" by civil society groups. Alternative reports are more likely to provide a critical perspective on activities of PMSCs than official ones. What is commendable, however, is that the committee is mandated to engage with other agencies and bodies towards soliciting assistance for state parties who have demonstrated need. ${ }^{109}$

\subsubsection{Dispute resolution}

${ }^{106}$ See McGoldrick D The Human Rights Committee: Its Role in the Development of the International Covenant on Civil and Political Rights (1994) 63.

107 Other treaty bodies have had to deal with this problem. For example, in 2006 the Human Rights Committee noted that Gambia had not submitted its reports for 21 years, Equatorial Guinea for 17 years, Somali and Nicaragua for 15 years, Bulgaria and Iran for 11 years, Jordan for 9 and Spain for 7 years. See Annual Report 2006 UN Doc A/61/40 (2005) Par 70-72.

108 Art 32.

${ }^{109}$ Art 32(7). 
The Committee handles disputes between state parties in relation to matters covered by the Convention. The dispute resolution function occurs at two levels. The first is what the Convention refers to as the "inquiry procedure" in article 33. Acting on information received about "grave or systematic violations" of the Convention, the Committee shall invite the state parties in whose territory the offences have occurred to "cooperate in the examination of the information" and submit observations. ${ }^{110}$ The committee together with states concerned will examine the information and, with agreement of parties, conduct a visit in loco. ${ }^{111}$ The findings of the committee together with its recommendations shall be communicated to the state(s) concerned. The whole process shall remain confidential.

This, however, is not unique. Under CEDAW a confidential enquiry may be undertaken if the committee receives reliable information indicating "grave or systematic" violations in the territory of a state party. ${ }^{12}$ It should be noted that, within the human rights field, an investigative fact-finding may be undertaken only in circumstances where the violations are grave or systematic, meaning that it should be more than just one incident. In the Draft Convention the language of "systematic or grave" violation has been used, not in relation to human rights or international humanitarian law violations, but in relation to "the provisions set forth in the Convention". The impression created, therefore, is that the Committee may undertake fact-finding if there is persistent neglect or refusal by a state party to impose licensing or other regulatory measures on PMSCs operating on its territory or if a state party declines to prosecute officials of a PMSC in line with the criminal law regime created by the Convention. In this regard it should be pointed out that the complementarity principle alluded to in article 38 of the Draft Convention could be instructive, and the Committee may be at liberty to defer its jurisdiction to other competent UN bodies.

The second level of dispute resolution involves complaints against parties as set out in article 34 of the Draft Convention. Here, two things are important. First, a state must recognise the competence of the Committee before complaints can be entertained or findings be made against it in relation to activities of PMSCs in their territory. Secondly, complaints will only be admissible based on the exhaustion-ofremedy rule and the generally recognised principles of international law. ${ }^{113}$ The procedure is similar to the enquiry process. The committee will receive complaints from members that consider other parties to have violated the provisions of the Convention. Subsequently, the complaint will be communicated to the party concerned which shall have the opportunity to respond. If the matter is not resolved through negotiations, the procedure under article 35 kicks in. The Committee shall

\footnotetext{
110 Art 33.

111 Contrast this with article 20 of CAT which mandates the CAT Committee to conduct an enquiry, including an on-site visit if it receives "reliable information" that torture is being practiced "systematically" in the territory of a state party to the Convention.

112 Art 8, Optional Protocol to CEDAW, adopted 1999.

113 Art 34(1)(b).
} 
then appoint an ad hoc Conciliation Commission comprising five members to facilitate an amicable solution or to make a finding on the dispute. ${ }^{114}$ The report of the Commission shall be communicated to the parties involved before being shared with all other state parties to the Convention. ${ }^{115}$

\subsubsection{Individual/group complaint mechanism}

A complex system of individual petition by victims of violation of the Draft Convention is created by article 37. A declaration of recognition of competence of the Committee must be made by state parties before this procedure can be invoked by their nationals. ${ }^{116}$ The Convention sets very stringent admissibility requirements that mirror other complaint systems, especially regional human rights systems. Under article 37(2) the communication must be anonymous; the violations complained of must not be investigated by another system or body; and all effective remedies must have been exhausted. A communication that meets the admissibility test is sent to the state party concerned for comments. On receipt of the comments, the Committee then examines the communication behind closed doors and thereafter communicate its findings to the state concerned and to the author of the communication. ${ }^{117}$ The committee may request state parties to consider taking interim measures before it examines the merits of the communication. ${ }^{118}$

A few general comments should be made before concluding this section. Firstly, there seems to be some lingering concerns that, unless the draft law puts together an improved system of handling individual complaints, the Working group shall have squandered a real chance to improve on the work of the UN treaty bodies. Undoubtedly, the Draft Convention should have been an innovative instrument embodying the wealth of knowledge accumulated from the experiences of older bodies such as the Human Rights Committee. Instead it is a dogmatic piece that seeks to balance interests rather than harness the power of the international community towards dealing with the PMSC problematique.

This leads to my second observation; that is, that the draft Convention should have built on the same experiences to broaden its regulatory reach rather than restrict it. One could take the example of the perennial problem of treaty bodies

114 Art 35(1).

115 Art 39.

116 In the earlier draft of the Convention, state parties wishing to recognise the competence of the Committee to receive such petition from their nationals had to make a declaration in this regard and then establish a national body that would be competent to consider such petitions. Individuals could only go to the Committee after they had failed to obtain "satisfaction" from the national body. This has been replaced by a more expedient procedure which is similar to other procedures of other individual complaint mechanisms.

117 Most treaty bodies deal with communications behind closed doors. The ECOSOC 1503 procedure, which is meant to deal with complaints related to systematic and gross human rights violations of human rights, is held in private.

118 Art 37(4). 
failing to produce remedies. ${ }^{119}$ The Draft Convention could have adopted the European approach where decisions of the European Court of Human Rights and recommendations of Ministers under the ECHR are legally binding on states. ${ }^{120}$ The argument could have been that, since the thrust of the Draft Convention's regulatory mandate is directed towards ensuring that corporate security entities observe the law, compliance with its regime should have some coercive force. After all, states have the latitude of imposing a compliance regime on PMSCs working within their territories that would ultimately absolve them from liability. Notwithstanding the above there is no excuse for not ensuring adequate capacity in the handling of reports and complaints, increasing media visibility for Committee decisions, or creating a viable nexus between the working of the Committee and other UN organs, regional bodies, NGOs and intra-governmental organisations, so that violations are reported in a timely manner and sanctioned through more than just one avenue.

\section{CONCLUSION}

The regulatory framework created by the Draft Convention is undoubtedly pitched at the ideology of free market as it accepts privatisation in the industry and affirms the distinction between legitimate private security operators and mercenaries. If its promise were to be judged on this score alone, its relevance to poorer nations could be contestable because these nations have, after all, not benefited much from neoliberalism. In my view, its promise is founded on its attempt to establish a hybrid regulatory framework that combines the essence of non-public approaches to security with public-oriented sanctions against undesirable conduct. Ironically, this may also be the reason, perhaps, that its regime may appear to be overly ambitious. But, to a large measure, this is also its strength. In the same way that its creation of "restrictive" universal standards for PMSCs may be seen as inimical to ideals of the free market, ${ }^{121}$ its recognition of the capacity of private entities to enter into legitimate contracts with states and international organisations will be applauded.

119 See for example, O'Flaherty M “Reform of the UN human rights treaty body System: Locating the Dublin Statement" (2010) 10 (2) Human Rights Law Review 319.

120 See European Convention on Human Rights, art 53. See also Zwaak L "The effects of the final decision of the supervisory organs under the European Convention on Human Rights" in Bayefsky A (ed) The UN Treaty System in the 21st Century (2000) 255.

121 This ideology is captured succinctly by the world trade regime established by the Marrakesh Treaty of 1994 which created the World Trade Organisation (WTO). The work of WTO is described in the Preamble to the agreement as leading to the "raising of standards of living, ensuring full employment and a large and steadily growing volume of real income ... while allowing for the optimal use of the world's resources in accordance with the objective of sustainable development, seeking both to protect and preserve the environment and to enhance the means for doing so in a manner consistent with [its members'] respective needs and concerns at different levels of economic development" (emphasis added). See Wouters J \& B. de Meester The World Trade Organization: A Legal and Institutional Analysis (2007) 13. See also Agarwal M "Issues of coherence in world trading system: A perspective from developing countries" (2006) 43 (2) International Studies 203. 
It also lays emphasis on the protection of human rights and observance of international humanitarian law and clarifies aspects of rules of international customary law, such as those relating to state responsibility. This undoubtedly places its regulatory framework within the body of established international norms, thereby broadening the base for state participation in international law and eliminating the chances that states will pick and choose which international regimes to abide by when dealing with PMSCs. Be that as it may, the success of the Draft Convention will ultimately depend on how its structures balance public security objectives with global economic, political and social trends. Its framework may not be perfect and, indeed, many of its provisions will still need to be refined, but the regulatory agenda that it proposes is one whose time has come.

\section{BIBLIOGRAPHY}

Abi-Saab G "The Uses of Article 19" (1999) 10 European Journal of International Law 339.

Amann D “Abu Gharib” (2005) 153(6) University of Pennsylvania Law Review 2085.

Appiah-Mensah S "AU's critical assignment in Darfur: Challenges and constraints" (2005) 14 (2) Africa Security Review 7.

Avant D The Market for Force: The Consequences of Privatising Security (Cambridge, 2005)

Baker D \& M Caporini (eds) Private Military and Security Companies: Ethics and Civil Military Relations London: Routledge (2008).

Bayefsky A "Human Rights and Direct participation: Direct participation in the UN Human Rights System" Proceedings of the Annual Meeting of the American Society of International Law Vol. 95 (2001) 71.

Bradley C "Unratified treaties, Domestic politics and the US constitution" (2007) 48(2) Harvard International Law Journal 307.

Browlie I Principles of Public International Law 7ed. Oxford: Oxford University Press (2008).

Casese A "The Nicaragua and Tadić tests revisited in light of the ICJ judgement on Genocide in Bosnia" (2007) 18(4) European Journal of International Law 649.

Chesterman S "Leashing the Dogs of War" (2005) 5(1) Carnegie Reporter 37. 


\section{PRIVATISATION, HUMAN RIGHTS AND SECURITY}

Chomsky N Profit and People: Neo-colonialism and Global Order (Seven Stories Press, New York, 1999)

Cockayne J Commercial Security in the Humanitarian Space: Blurring Boundaries or Building States New York: International Peace Academy (2006).

Cockayne, J "Regulating Private Military and Security Companies: The Content, Negotiation, Weakness and Promise of the Montreux Document" (2009) 13(3) Journal of Conflict \& Security Law 401.

Conteh K "Security Sector Reform in Sierra Leone and the Role of the Office of the National Security" in Jackson P \& P Albretch (eds) Issues and Themes of Sierra Leone Security System Transformation Process 1997-2007 London: International Alert (2008) 9.

Cowling M "Outsourcing and Military: Implications for international humanitarian law" (2007) 32 South African Yearbook of International Law 313.

Crawford J \& S Olleson "The Nature and forms of international responsibility" in Evans M (ed) International Law 2ed Oxford: Oxford University Press (2006) 458.

De Hoogh A Obligations Erga Omnes and International Crimes The Hague: Kluwer (1996).

Del Prado JG "Private and security Companies and the UN Working Group and the Use of Mercenaries" (2009) 13 (3) Journal of Conflict \& Security Law 429.

Devenmack R \& M Hoffman "Just scraps of paper? Dynamics of multilateral treaty making” (2008) 43 (2) Cooperation and Conflict 185.

Fleck D et al The Handbook of Humanitarian Law in Armed Conflict Oxford: Oxford University Press (2000) 95.

Francis D "Mercenary intervention in Sierra Leone: Providing national security or international exploitation" (1999) 20 Third World Quarterly 319.

Gaston E "Mercenaries 2.0? The rise of the modern private security industry and its implications for international law enforcement" (2008) 49 (1) Harvard International Law Journal 221.

Georghiades $\mathrm{K}$ "The Ottawa Convention: meeting the challenges of anti-personnel mines" (1998) 14(3) International Relations 51.

Gillard "Business goes to war: Private military/security companies and international humanitarian law" (2006) 85 International Review of the Red Cross 525.

Hoppe C "Passing the buck: State responsibility for private military companies" (2008) 19 (5) European Journal of International Law 991. 
International Committee of the Red Cross (ICRC), Interpretive Guidance on the Notion of Direct participation in Hostilities under International Humanitarian Law, (prepared by N Melzer) Geneva, ICRC (2009).

Jensen N \& L Wantchekon "Resource Wealth and political regimes in Africa" (2004) 37(7) Comparative Political Studies 816.

Jørgensen N The Responsibility of States for International Crimes Oxford: Oxford University Press (2003).

Juma L "The war in Congo: Shadow networks and the failure of internationalism" (2006) 10(2) Gonzaga Journal of International Law 97.

Kervers D "Strengthening Compliance with the Biological Weapons conventions: The protocol negotiations" (2002) 7(2) Journal of Conflict Security Law 275.

Kiss A "State responsibility and liability for nuclear damage" (2005) 35 (1) Denver J. Int'l. L. \& Pol. 67

Kretzmer D "Civilian Immunity: Legal aspects" in Promoratz I (ed) Civilian Immunity in War Oxford: Oxford University Press (2007) 91.

Kurtz M "The social foundations of institutional order: Reconsidering war and resource in third world state building" (2009) 37 (4) Politics \& Society 479.

Lee S \& McBride S "Introduction" in Lee S \& McBride S (ed) Neo-Liberalism, State Power and Global Governance in the Twenty First Century Springer (2007) 1.

Lehnardt C "Individual liability of private military personnel under international criminal law" (2008) 19 (5) European Journal of International Law 1051.

Lujala P et al "Diamond a curse? Civil war and a 'lootable' resource" (2005) 49 (4) Journal of Conflict Resolution 538.

Malanczuk P "The International Criminal Court and landmines: what are the consequences of leaving US behind?" (2000) 11(1) European Journal of International Law 77.

McGoldrick D The Human Rights Committee: Its Role in the Development of the International Covenant on Civil and Political Rights Oxford: Clarendon (1994).

McQuoid-Mason D "The Role of Human Rights Institutions in South Africa" in K Hossain et al (eds) Human Rights Commissions and Ombudsman Offices The Hague: Kluwer (2000) 618.

Messner J "Working towards effective legislative and regulatory solutions for private security industry in Africa" in Gumedze S (ed) Elimination of Mercenarism in Africa: A Need for a New Continental Approach Pretoria: ISS (2008) 145. 
Michaels J "Beyond accountability: The constitutional democratic and strategic problem with privatising war" (2004) 82 Washington University Law Quarterly 1001.

Michie A "The provisional application of arms control treaties" (2005) 10(3) Journal of Conflict \& Security Law 345.

Musah A \& Kayode J Mercenarism: An African Security Dilemma London: Pluto Press (2000).

Okafor 0 \& S Agbakwa "On Legalism, Popular Agency and "Voices of Suffering": The Nigerian National Human Rights Commission in Context" (2002) 24 Human Rights Quarterly 662.

Pellet A "A New Draft Articles of the International Law Commission...A Requiem for States' Crime" (2001) 32 Netherlands YBIL 55.

Prins B \& B Marshall "Senate influence or presidential unilateralism? An examination of treaties and executive agreements for Theodore Roosevelt and George Bush" (2008) 26 (2) Conflict Management and Peace Science 191.

Reif L "Building Democratic Institutions: The Role of National Human Rights Institutions in Good Governance and Human Rights Protection" (2000) 13 Harvard Human Rights Journal 1.

Reus-Smit C "The constitutional structure of the international society and the nature of fundamental institutions" (1997) International Organizations 555.

Rinkema R "Environmental agreements, non-state actors, and the Kyoto Protocol: A third way for international climate action" (2003) 24 (3) University of Pennsylvania Journal of International Economic Law 729.

Ross M "What do we know about natural resource and civil war?" (2004) 41 (3) Journal of Peace Research 337.

Schmidt M "Deconstructing direct participation in hostilities: The constitutive elements" (2010) 42 International Law \& Politics 697.

Singer P Corporate Warriors: The Rise of Privatized Military Industry Ithaca: Cornel University Press (2003).

Spearin C "Private security companies and humanitarians: A corporate solution to securing humanitarian space" (2001) 8 (1) International Peacekeeping 24.

Stinnet N "Regulating the privatization of war: How to stop private military from committing human rights abuses" (2005) Boston College International \& Comparative law Review 211. 
Strydom H "An overview of the UN Draft Convention on Private Military and Security Companies" (2009) African Yearbook on International Humanitarian Law 121.

Van Woudenberg $\mathrm{N}$ "The long and winding road towards an instrument on cluster munitions" (2007) 12(3) Journal of Conflict Security Law 447.

Vité S "Typology of Armed conflicts in international humanitarian law: Legal concepts and actual limitations" (2009) 91 International Review of the Red Cross 69.

Wolfrun R "State responsibility for private actors: An old problem of renewed relevance" in Ragazzi M (ed) International Responsibility Today Brill (2005) 424.

Zarate J "The emergence of the new dogs of war: private international security companies, international law, and the new world disorder" (1998) 34 Stanford Journal of International Law 75.

Zwaak L "The effects of the final decision of the supervisory organs under the European Convention on Human Rights" in Bayefsky A (ed) The UN Treaty System in the $21^{\text {st }}$ Century The Hague: Kluwer (2000) 255.

\section{Electronic sources}

Dacey J "Swiss fired up over arrival of mercenary firm" Swiss.info.ch at http://www.swissinfo.ch/eng/business/Swiss_fired_up_over_arrival_of_mercenary_fir m.html?cid=22482084) (accessed 1 November 2010).

Gumedze S "Addressing the use of private security and military companies at the international level" ISS Paper 201, November 2009 at http://idlbnc.idrc.ca/dspace/bitstream/10625/41432/1/129208.pdf (accessed 20 June 2010).

Harvey D "Neo-Liberalism as Creative Destruction" (2007) 2 (4) Interfacehs at http://www.interfacehs.sp.senac.br/images/artigos/79 pdf.pdf (accessed 17 April 2011).

Harwood M "ASIS members sign private security contractors code of conduct" at http://www.securitymanagement.com/news/asis-members-sign-private-securitycontractor-code-conduct-007877 (accessed 22 November 2010).

Lynch C "UN Embraces Private Military and Security Companies" at http://turtlebay.foreignpolicy.com/posts/2010/01/17/un_embraces_private_military_co ntractors (accessed 20 October 2010).

Ralby I "Regulating private security in Sierra Leone" (2010) 5(4) PeaceOps: Journal of International Peace Operations at http://web.peaceops. com/archives/153 (accessed 2 November 2010). 


\section{PRIVATISATION, HUMAN RIGHTS AND SECURITY}

Schmidt M "Direct Participation in Hostilities and 21 ${ }^{\text {st }}$ Century Armed Conflict" in Fischer $\mathrm{H}$ et al (eds) Festschrift Für Dieter Fleck (2004) 505 at www.michaelschmidt.org/images/directparticipationproofs.pdf (accessed 26 October 2010).

Smith R "British Mercenary not welcome in Switzerland" Linksunten.Indymedia.org, available at http://linksunten.indymedia.org/de/node/26589) (accessed 1 November 2010)

http://www2.ohchr.org/english/issues/mercenaries/docs/A.HRC.15.25.pdf) (accessed 30 October 2010).

http://www.reliefweb.int/rw/rwb.nsf/db900SID/EGUA-7QWSR7?OpenDocument (accessed 25 October 2010). 